\title{
Analysis of energy management strategies for hybrid electric vehicles in urban driving conditions
}

The pursuit of fuel consumption reduction by vehicles leads to a sudden increase in the share of hybrid and electric drives in the vehicle market. Replacing hybrid vehicles with electric vehicles requires long-term technological solutions, both for the infrastructure and the vehicles themselves. Therefore, one of the leading types of passenger car drives is currently the hybrid drive. The generated work share of electric drives used to power hybrid vehicles is a determinant of the viability of using electric drives. The article estimates the operating time share of electric and hybrid modes operation in real driving conditions (RDC) based on the latest Toyota hybrid model. The research object was a vehicle from the crossover group equipped with a fourth generation hybrid drive. Analysis of the drive's operation allowed to determine the conditions of energy flow and determine the work share of the electric drive in the total driving time.

Key words: hybrid electric vehicles, energy management, electric range, real driving conditions

\section{Introduction}

For a long time, due to economic and ecological aspects, solutions have been sought that would minimize the use of conventional fuels in transport. Such solutions are used in various branches of transport, including in road, rail and even air transport $[7,11]$. One of the proposed solutions is the use of a hybrid drive containing at least two sources of power and energy. The most common system includes a spark-ignition engine and an electric motor. In 2016, road transport accounted for the transport of $84.2 \%$ of all cargo [1]. However, the share of passengers transported by this type of transport amounted to $56.2 \%$. Considering this data, it seems justified that the majority of effort in the field of reducing emissions to the environment is carried out towards road transport.

It has been 20 years since the first serial production of full hybrid vehicles by Toyota [4, 8, 9]. During this time the company has been developing the hybrid drive system through several iterations $[6,10,12,19]$.

The current technological trend of reducing emissions from vehicles are technologies that allow the use of alternative fuels or alternative drives themselves. Tests of vehicles powered with alternative fuels (ethanol, CNG, bi-fuel) or with alternative propulsion systems (full and mild hybrid system) are carried out with respect to energy flow [3, 13, 14, 19] and their harmful components emissions in real operating conditions and in RDE (Real Driving Emissions) tests [5, 15-17].

\section{Aim of research}

At present, there is a strong emphasis in the construction of hybrid vehicles on increasing their travel range in electric mode. This means an increased share of electric motor operation in the total operating time of the hybrid system [2]. In order to demonstrate the electric mode work participation, tests were conducted in urban driving conditions. The practical goal of the conducted research was to analyze the energy flow in the latest generation hybrid drive system on the example of Toyota C-HR and indication of the actual shares of electric and hybrid drive time when driving in urban conditions.

\section{Research object}

The Toyota C-HR vehicle, which was used to test the hybrid drive system in urban driving conditions, has a propulsion system construction similar that of the newest 2015 Toyota Prius (IV generation). The basic parameters of the drive system components are presented in Table 1.

Table 1. Test vehicle technical data [18]

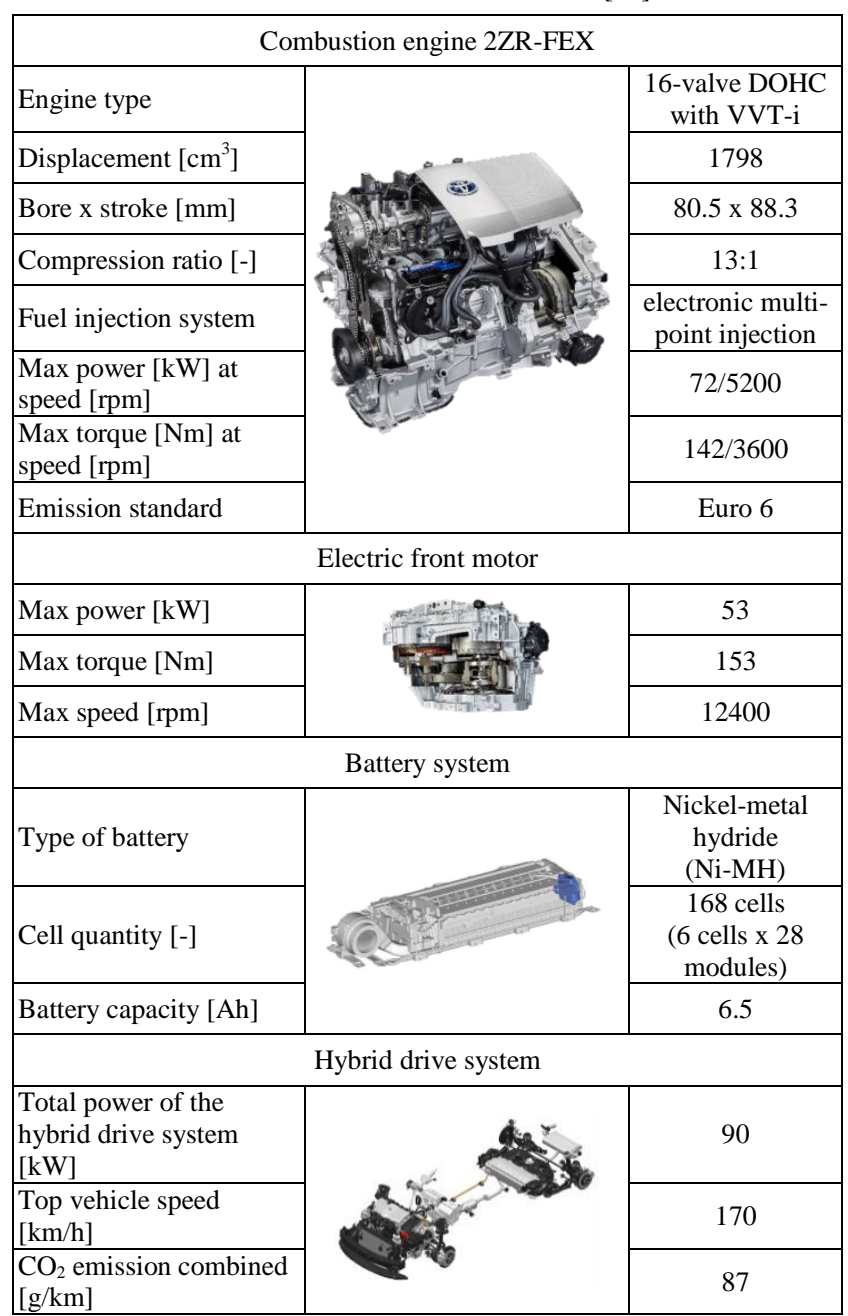


The hybrid drivetrain consists mainly of a $1.8 \mathrm{dm}^{3}$ Atkinson-cycle petrol engine (assembled at the Toyota plant in Derby), a $1.31 \mathrm{kWh}$ HV battery, and an electric motor all tied together by Toyota's planetary gear transmission. The effect of combining these motors provides $90 \mathrm{~kW}(120$ $\mathrm{KM}$ ) of power and $142 \mathrm{Nm}$ of torque at $3600 \mathrm{rpm}$.

The Toyota C-HR is equipped with a fourth-generation hybrid drive. The structure of the drive is a series-parallel system (the scheme and principle of operation are described in [9]), shown in Fig. 1 together with the measuring devices used during the tests. The drive consists of a battery, planetary gear, generator, electric motors and an internal combustion engine.

The hybrid drive is mainly meant for use in urban driving, due to the frequency and intensity of traffic, which is associated with acceleration changes and thus, the ability to recover more energy from braking.

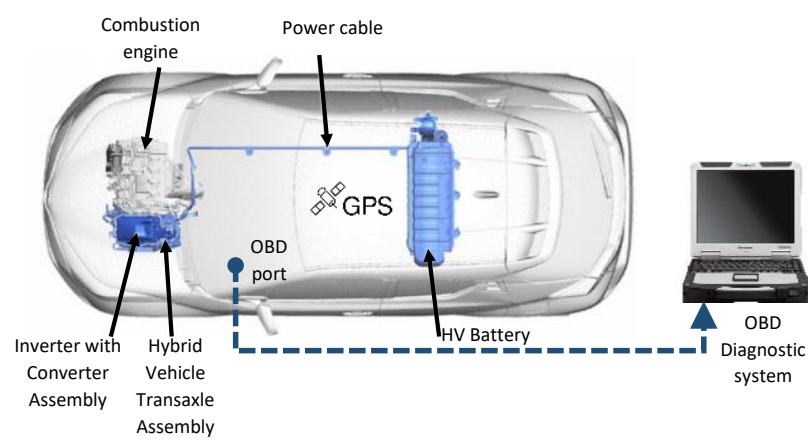

Fig. 1. A schematic of Toyota C-HR hybrid drive system along with the applied measuring devices (based on [18])

Toyota hybrid cars have four drive modes: Normal, EV, ECO and Power. After first starting the car, the system default settings is the 'Normal' drive mode, which automatically manages the most efficient use of both engines. Driver can also select one of the car's on-demand drive modes to achieve better fuel consumption in certain circumstances. Two of these modes, ECO and EV, were analysed in this article.

\section{Research methodology}

The tests were carried out in Warsaw in real driving conditions on a regular work day. Two drive modes of Toyota C-HR have been compared. The first test was performed with the ECO drive setting, and the other in the ECO setting but with the EV mode active. (further referred to as ECO + EV), Traffic congestion was observed during tests (traffic volume higher than the capacity of a given road). The average route length (Fig. 2) was $11.5 \mathrm{~km}$, and the average test duration was 32.2 minutes.

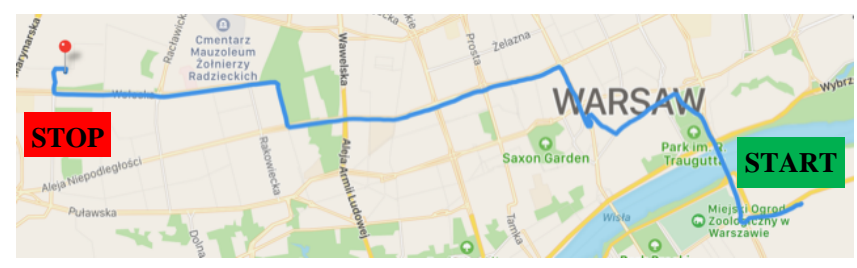

Fig. 2. Map of the road tests route
In order to record the vehicle motion parameters and hybrid drive operating conditions, a diagnostic system was connected that allows reading data directly from the hybrid drive monitor system. The following values were recorded in the tests: vehicle speed (S), combustion engine speed (n), battery charge status (SOC), electric motor speed and battery current (IB - positive value was defined as charging the battery, and negative indicates battery discharge). In addition, an independent system recorded the geographical position of the vehicle to determine the route. The characteristic drive conditions are shown on Fig. 3 and in Table 2. The conditions in both of the drives are similar and any differences negligible. Therefore, it can be assumed that the tests were repeatable, allowing for further comparative analysis of the drive system parameters depending on the selected driving mode.

a)

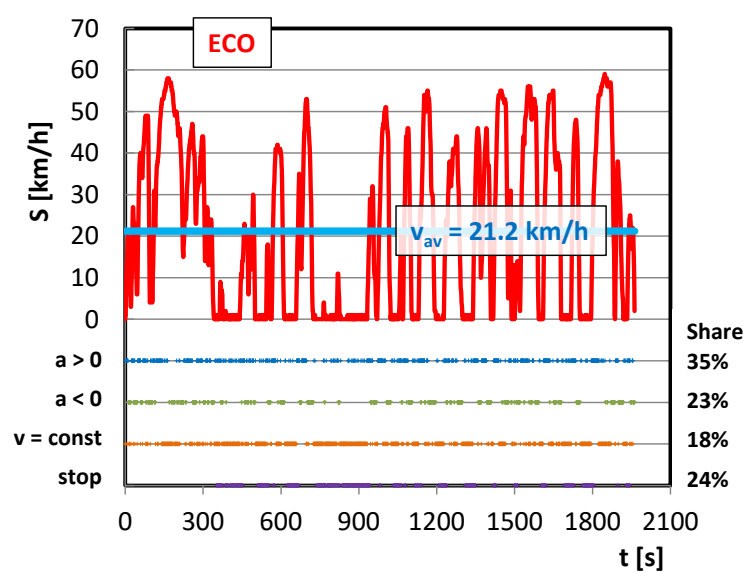

b)

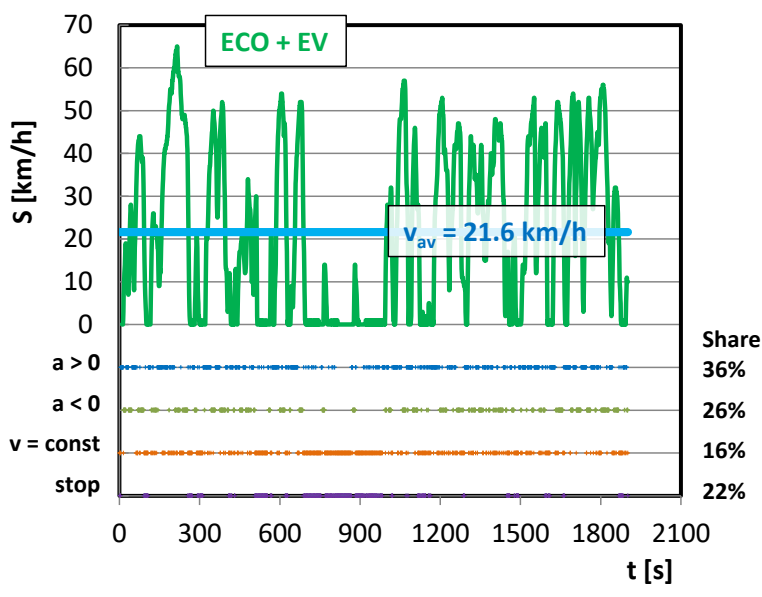

Fig. 3. The route drive characteristics with marked time densities of acceleration, constant speed, braking and stopping of the vehicle in the repeated drives on the same route: a) ECO mode, b) ECO + EV mode

Table 2. Test conditions for hybrid drive in two driving modes

\begin{tabular}{|l|c|c|}
\hline Marameter & ECO & ECO + EV \\
\hline Test duration [s] & 1962 & 1902 \\
\hline Test route length [m] & 11,554 & 11,437 \\
\hline SOC (initial/final) & $60.4 / 47.5$ & $47.5 / 60.4$ \\
\hline
\end{tabular}


To determine the share of the electric mode driving, sections of the route characterized by certain specific parameters were determined. Thus, the modes of operation of the hybrid drive system were determined: driving, acceleration and braking during the operation of the hybrid drive (HV), as well as vehicle standstill, driving, acceleration and braking with the internal combustion engine not active, i.e. drive system operation in electric mode (EV). The adopted criteria are listed and presented in Table 3.

The energy flow in the drive system during battery discharging, charging and recuperative braking was also calculated:

energy flow:

$$
\Delta \mathrm{E}=\mathrm{U} * \mathrm{I} * \Delta \mathrm{t}
$$

discharging:

$$
\Delta \mathrm{E}_{\mathrm{dis}}=\mathrm{U} * \mathrm{I} * \Delta \mathrm{t}(\text { if } \Delta \mathrm{E}<0)
$$

charging:

$$
\Delta \mathrm{E}_{\mathrm{ch}}=\mathrm{U} * \mathrm{I} * \Delta \mathrm{t}\left(\text { if } \Delta \mathrm{E}>0 \text { and } \mathrm{M}_{\mathrm{reg}} \geq 0\right)
$$

recuperative braking:

$$
\Delta \mathrm{E}_{\mathrm{reg}}=\mathrm{U} * \mathrm{I} * \Delta \mathrm{t}\left(\text { if } \Delta \mathrm{E}>0 \text { and } \mathrm{M}_{\mathrm{reg}}<0\right)
$$

where:

$\mathrm{U}$ - voltage [V], I - current [A], $\Delta \mathrm{t}$ - time [h], $\mathrm{M}_{\mathrm{reg}}$ - braking torque $[\mathrm{Nm}]$.

Table 3. Criteria for determining individual modes during the test

\begin{tabular}{|l|l|}
\hline Mode & Parameters \\
\hline HV drive & $\mathrm{a}=0, \mathrm{n}>600, \mathrm{v}>0$ \\
\hline EV drive & $\mathrm{a}=0, \mathrm{n}<600, \mathrm{v}>0$ \\
\hline HV acceleration & $\mathrm{a}>0, \mathrm{n}>600, \mathrm{v}>0$ \\
\hline EV acceleration & $\mathrm{a}>0, \mathrm{n}<600, \mathrm{v}>0$ \\
\hline standstill & $\mathrm{v}=0$ \\
\hline braking & $\mathrm{a}<0, \mathrm{v}>0, \mathrm{n}>600$ \\
\hline EV braking & $\mathrm{a}<0, \mathrm{v}>0, \mathrm{IB}>0, \mathrm{n}<600$ \\
\hline
\end{tabular}

\section{Results analysis}

The energy flow rates were calculated with the formulas (1)-(4) and Table 3. The charging of the battery, its discharging and the regenerative braking conditions have been taken into account. The results are shown in Fig. 3 and 4. The energy flow rate is influenced also by the state of charge of the battery, both the initial and the final values (Fig. 4).

Driving in ECO mode results in increased energy flow values (up to $0.23 \mathrm{kWh}$ ) compared to the $\mathrm{ECO}+\mathrm{EV}$ mode (up to $0.03 \mathrm{kWh}$ ). This is due to the lower initial charge status of the battery $(\mathrm{SOC}=47 \%)$. Using the $\mathrm{ECO}+\mathrm{EV}$ mode means that the battery discharge time density is much greater than during the ECO mode (by 37\%). In spite of the varied changes in the discharge energy, the battery charging and energy recovery modes have similar energy flow shares. The differences do not exceed $11 \%$ (for charging) and $8 \%$ for regenerative braking.
Analysis of the energy flow change (Fig. 4) indicates significant similarities to the battery charge level. There are noticeable changes in the energy flow proportional to the battery charge level. However, it is not possible to specify the proportionality value. During the battery discharge $(\mathrm{ECO}+\mathrm{EV}$ mode) changes in both these quantities are proportional in varying degrees.
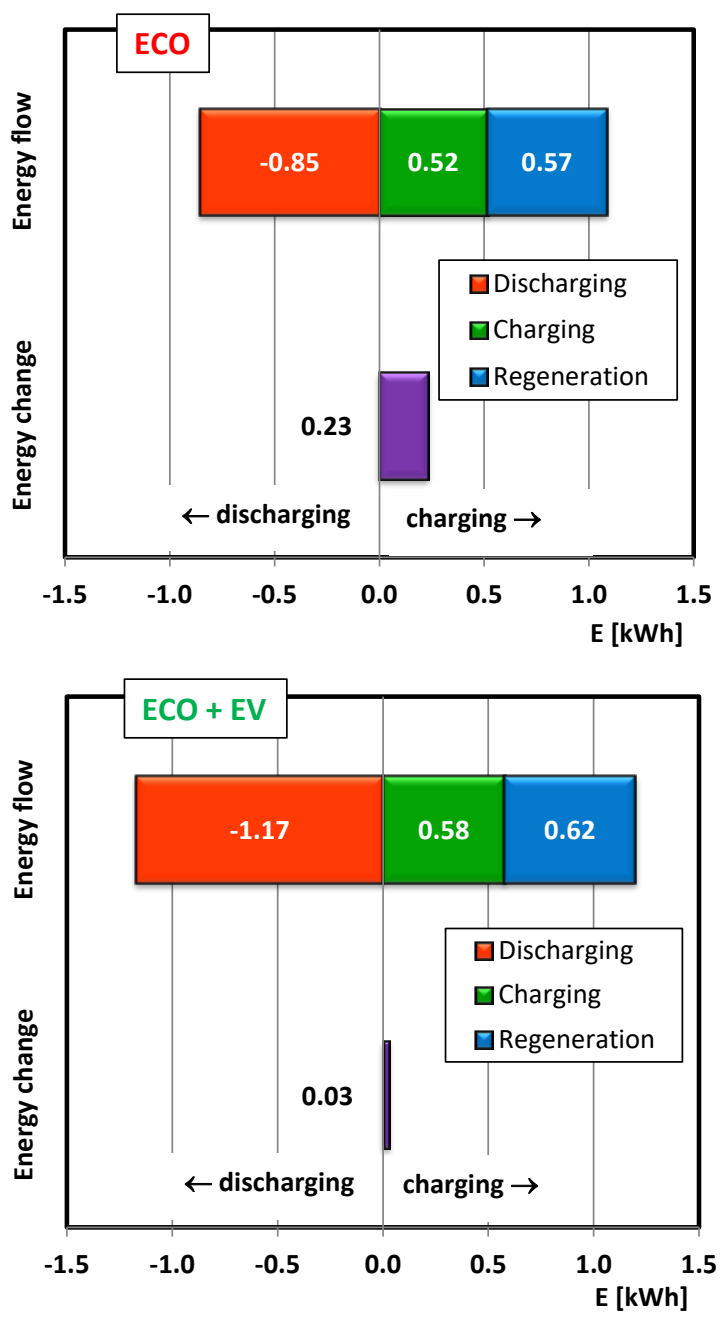

Fig. 3. Energy flow to/from the battery in a hybrid drive in urban conditions (negative values indicate discharging the battery)

From the data in Table 3 the operating time density of individual vehicle driving modes have been calculated. The results were presented in terms of both the time and the distance traveled (the differences in the result are from the vehicle's standstill).

The data comparison is included in Fig. 5, where the distance and time are shown in relative terms. Despite the different driving modes, there are significant similarities in the time densities of individual driving modes. Driving in electric mode at a constant speed (a0 EV) and braking in this driving mode $(\mathrm{a}-\mathrm{EV})$ represent high total drive time contributions. Their shares are large both in relation to the test route distance and the total travel time.

Using these analyzes, the percentage share of electric mode operation time was determined, this was done by summing the values of the EV system operation modes, i.e. 
driving without the active combustion engine, acceleration and braking with energy recovery without the internal combustion engine being on. The obtained results are compared in Fig. 6.
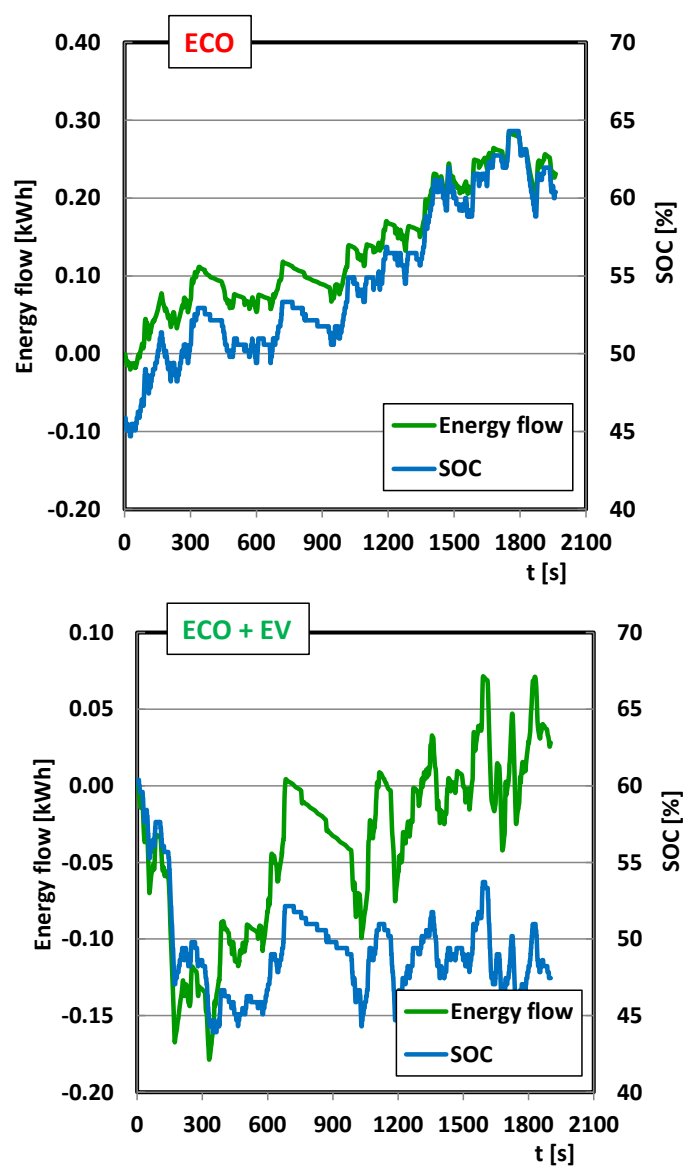

Fig. 4. Comparison of energy flow and changes in battery charge
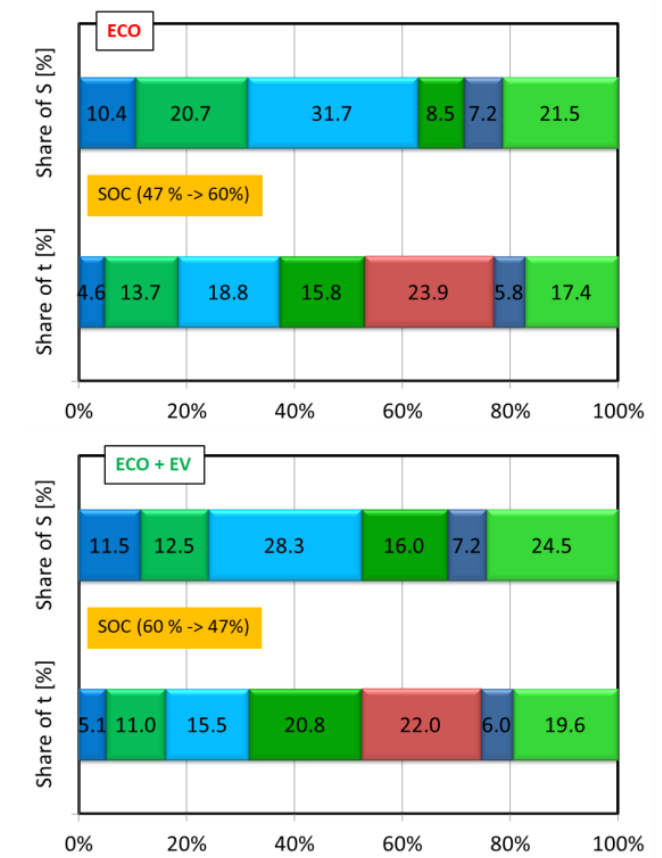

口a0 HV $\square \mathrm{aO}$ EV $\square \mathrm{a}+\mathrm{HV} \square \mathrm{a}+\mathrm{EV} \square \mathrm{stop}$ 口a- HV $\square \mathrm{a}-\mathrm{EV}$

Fig. 5. The percentage share of individual driving modes in relation to time and distance traveled during the test

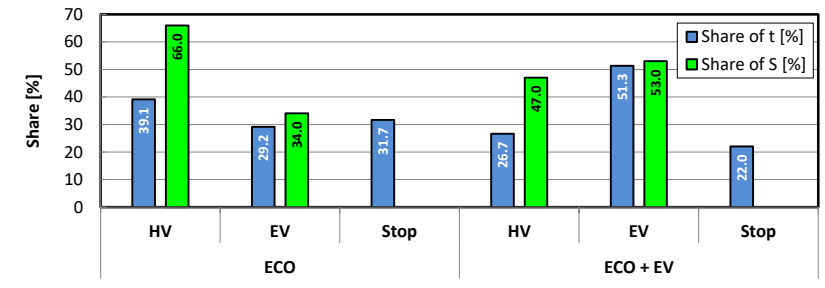

Fig. 6. The share of hybrid and electric mode in urban traffic conditions in relation to the road and time of the vehicle test drive

After summing up individual vehicle energy flow types in electric mode, the EV mode participation in the overall drive was determined (Fig. 6).

\section{Conclusions}

Based on the obtained results, it can be stated that the latest hybrid vehicles are characterized by a larger share of the system's operation in electric mode than in the hybrid mode. The percentage share of the electric mode operation was in the range $51 \%-53 \%$ of the distance traveled and about 46 $51 \%$ of the test duration (depending on the test). The final percentage result is influenced by many factors, including the current traffic volume, vehicle load, initial high-voltage battery charge (SOC), standstill time at the intersection with traffic lights, and the driving style of the driver.

The performed tests in urban conditions indicate, the share of energy recovery from regenerative braking is over $50 \%$ of all energy supplied to the battery while driving (from both charging from the generator and regenerative braking). This indicates the efficiency of energy recovery from braking and indicates the desired energy flow (battery charge) in the hybrid drive system. Braking energy recovery, a significant share of electric drive operation, operating costs reduction, lower emission of harmful and toxic compounds into the environment without significant financial costs are undoubtedly arguments in favor of using hybrid drives.

The obtained results apply to currently used vehicles with hybrid drive systems using Ni-MH batteries. The share of hybrid vehicles in electric mode with Li-Ion batteries in use (vehicles that can also be charged from a plug-in electrical socket) should be much larger. This is influenced by the much larger electric capacity of the batteries and the higher discharge values relative to the nickel-metal hydride batteries. However, this solution is also associated with much greater battery pack mass and dimensions. When choosing a vehicle, its place of exploitation should be taken into account. In the hybrid systems of current vehicles with $\mathrm{Ni}-\mathrm{MH}$ batteries, the usefulness of a vehicle in urban traffic means a reduction of the classic internal combustion engine use by more than $50 \%$. However, this trend will not be reflected in vehicles used on non-urban routes, where an increased operating time share of the internal combustion engine is necessary to achieve higher vehicle speeds.

The research presented in this paper was performed within the statutory work, project no. 05/52/DSMK/0265.

\section{Acknowledgement}

The authors would like to thank Mr Andrzej Szalek - representatives at Toyota and Lexus Academy in Toyota Motor Poland Company Ltd. in Warsaw, Poland for their provision of an vehicle for testing. 


\section{Nomenclature}

\begin{tabular}{|c|c|c|c|}
\hline $\mathrm{a}$ & acceleration & $\mathbf{M}_{\text {reg }}$ & braking torque \\
\hline $\mathrm{CNG}$ & compressed natural gas & $\mathrm{n}$ & engine speed \\
\hline $\mathrm{CO}_{2}$ & carbon dioxide & $\mathrm{NiMH}$ & nickiel hydride battery \\
\hline $\mathrm{E}$ & energy & $\mathrm{RDC}$ & real driving conditions \\
\hline $\mathrm{ECO}$ & eco mode & $\mathrm{RDE}$ & real driving emission \\
\hline $\mathrm{EV}$ & electric vehicle & $\mathrm{SOC}$ & state of charge \\
\hline $\mathrm{HEV}$ & hybrid electric vehicle & $\mathrm{S}$ & vehicle speed \\
\hline I & current & $\mathrm{t}$ & time \\
\hline IB & battery current & $\mathrm{U}$ & voltage \\
\hline Li-Ion & lithium-ion battery & $\mathrm{V}$ & velocity \\
\hline
\end{tabular}

\section{Bibliography}

[1] Central Statistical Office. Transport - results of operations in 2016, www.stat.gov.pl (accessed 26.11.2017).

[2] CIEŚLIK, W., PIELECHA, I. SZAŁEK, A., Indexes of performance of combustion engines in hybrid vehicles during the UDC test. Combustion Engines. 2015, 160(1), 14-27.

[3] HUTCHINSO, T., BURGESS, S., HERRMANN, G. Current hybrid-electric powertrain architectures: Applying empirical design data to life cycle assessment and whole-life cost analysis. Applied Energy. 2014, 119, 314-329, DOI: 10.1016/j.apenergy.2014.01.009.

[4] IWATA, K., MATSUMOTO, S. Use of hybrid vehicles in Japan: An analysis of used car market data. Transportation Research Part D: Transport and Environment. 2016, 46, 200-206. DOI: 10.1016/j.trd.2016.03.010.

[5] KAPUSTIN, A., RAKOV, V. Methodology to evaluate the impact of hybrid cars engine type on their economic efficiency and environmental safety. Transportation Research Procedia. 2017, 20, 247-253. DOI: 10.1016/ j.trpro.2017. 01.057.

[6] KISHI, H.T. Towards Sustainability - Toyota's way to develop the next generation vehicles. 38. Internationales Wiener Motorensymposium. 2017.

[7] KORTAS, P., KROPIWNICKI, J. Analysis of accumulation possibility of energy dissipated in the braking process of train driven by hybrid locomotive. Combustion Engines. 2015, 162(3), 631-638.

[8] MATSUBARA, T., YAGUCHI, H., TAKAOKA, T. et al. Development of new hybrid system for compact class vehicles. SAE Technical Paper 2009-01-1332, 2009. DOI: 10.4271/2009-01-1332.

[9] MATSUMURA, M., SHIOZAKI, K., MORI, N. Development of new hybrid transaxle for mid-size vehicle. $S A E$ Technical Paper 2018-01-0429, 2018. DOI: 10.4271/201801-0429.

Prof. Ireneusz Pielecha, DSc., DEng. - Faculty of Machines and Transport, Poznan University of Technology.

e-mail: Ireneusz.Pielecha@put.poznan.pl

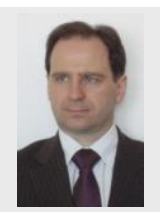

Kinga Fluder, MEng. - Faculty of Machines and Transport, Poznan University of Technology.

e-mail: Kinga.Fluder@student.put.poznan.pl

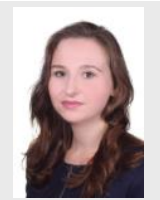

[10] MERKISZ, J., PIELECHA, I. Mechanical systems for hybrid vehicles. 2015, Publishing House Poznan University of Technology.

[11] MERKISZ, J., PIELECHA, J. Nanoparticle emissions from combustion engines. Springer Tracts on Transportation and Traffic. 2015, 8, Springer International Publishing Switzerland.

[12] OSHIMA, K., KATO, S. New multi stage hybrid system for the LC500h with innovative drivability of the THSII. 39. Internationales Wiener Motorensymposium. 2018.

[13] PIELECHA, I., CIEŚLIK, W., SZAŁEK, A. Operation of electric hybrid drive systems in varied driving conditions. Eksploatacja i Niezawodnosc - Maintenance and Reliability. 2018, 20(1), 16-23. DOI: 10.17531/ein.2018.1.3.

[14] PIELECHA, I., CIEŚLIK, W., SZAŁEK, A. Operation of hybrid propulsion systems in conditions of increased supply voltage. International Journal of Precision Engineering and Manufacturing. 2017, 18, 1633-1639. DOI: 10.1007/ s12541-017-0192-3.

[15] PIELECHA, J., MERKISZ, J., MARKOWSKI, J. et al. Analysis of passenger car emission factors in RDE tests. International Conference on the Sustainable Energy and Environment Development, SEED, 2016. DOI: 10.1051/e3sconf/ 20161000073

[16] SAXENA, S., PHADKE, A,, GOPAL, A. Understanding the fuel savings potential from deploying hybrid cars in China. Applied Energy. 2014, 113, 1127-1133. DOI: 10.1016/j.apenergy. 2013.08.057.

[17] STELMASIAK, Z., LARISCH, J., PIELECHA, J. et al. Particulate matter emission from dual fuel diesel engine fuelled with natural gas. Polish Maritime Research. 2017, 24(2), 96-104. DOI: 10.1515/pomr-2017-0055.

[18] toyota-tech.eu (accessed 10.01.2018)

[19] WILBERFORCE, T., EL-HASSAN, Z., KHATIB, F.N. et al. Developments of electric cars and fuel cell hydrogen electric cars. International Journal of Hydrogen Energy. 2017, 42(40), 25695-25734. DOI: 10.1016/j.ijhydene.2017. 07.054 .

Wojciech Cieślik, DEng. - Faculty of Machines and Transport, Poznan University of Technology.

e-mail:Wojciech.Cieslik@put.poznan.pl 